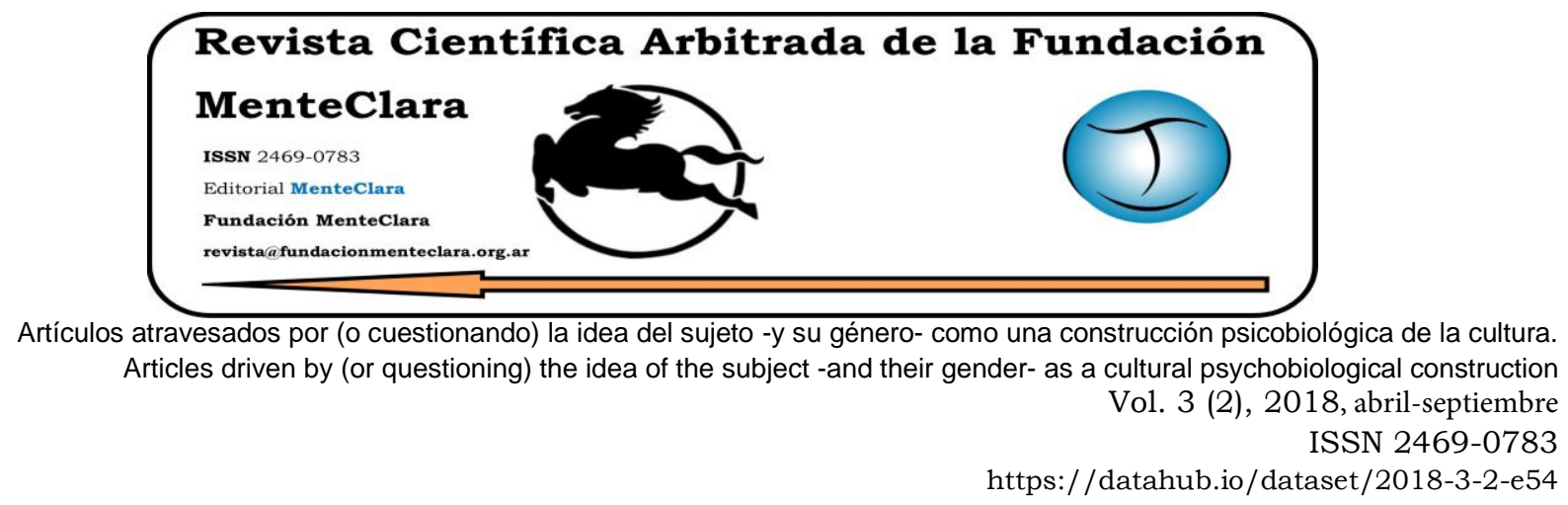

\title{
PHENOMENOLOGY OF RESPIRATION AND THE SENSE OF WHONESS WITHIN TANTRA AS PERSONHOOD
}

\author{
FENOMENOLOGÍA DE LA RESPIRACIÓN Y EL SENTIDO DE IDENTIDAD EN EL \\ TANTRA COMO CATEGORÍA DE PERSONA
}

Rudolph Bauer rbauer@rsbauer.net

Center for Consciousness Studies and Washington Center for Phenomenological and Existential Psychotherapy Studies. United States of America

Cómo citar este artículo / Citation: Bauer R. (2018). "Phenomenology of Respiration and the Sense of Whoness within Tantra as Personhood". Revista Cientifica Arbitrada de la Fundación MenteClara, 3(2) abril-septiembre 2018, 147 158. DOI: https://doi.org/10.32351/rca.v3.2.54

Copyright: (C) 2018 RCAFMC. Este artículo de acceso abierto es distribuido bajo los términos de la licencia Creative Commons Attribution-Non Commercial (by-cn) Spain 3.0. Recibido: 21/08/2018. Aceptado: 05/09/2018 Publicación online: $19 / 10 / 2018$

Conflicto de intereses: Ninguno que declarar.

\begin{abstract}
When the Spaceousness of the breathless breath opens, who-ness can be felt as uncontained and unbound. Who-ness is experiential openness...openness prior to mind. Dasein to use Heideggarian language. Most often there is this intertwining of breath and respiration, intertwining of breath and qi, intertwining of breath and Shakti, breath and primordial energy. Respiration inspires us and respirates us. Utimately, this energy of respiration is light. Illumination is forming forms of light as energy and the light becoming energy becoming respiration. Tantra is intimately connected to this subtle phenomena of respiration.
\end{abstract}

\section{Resumen}

Cuando se abre la amplitud de la respiración acelerada, la identidad personal puede sentirse como incontenible y desatada. La identidad personal es apertura 
experiencial... apertura previa a la mente. Dasein para usar terminología heideggeriana. Lo que suele haber es un entrelazamiento de respiración y respiración aeróbica, entrelazamiento de respiración y qi, entrelazamiento de respiración y Shakti, respiración y energía primordial. La respiración aeróbica nos inspira y nos respira. En el fondo, la energía de esta respiración aeróbica es luz. La iluminación está formando formas de luz como energía y la luz se convierte en energía y se convierte en respiración aeróbica. El tantra está íntimamente relacionado con este sutil fenómeno de la respiración aeróbica.

\section{Palabras Claves/ Keywords}

Respiration; Breathless Breath; Whoness; Tantra; Respiración aeróbica; Respiración acelerada; identidad personal 


\section{Introduction}

The felt sense of whoness is not a me-ness...me is self-fixation and in fact the sense of whoness can free us from objectified self-fixation. The sense of me often replaces the sense of who. When the experiential nonconceptual felt sense of who is not known or experienced, the felt sense of me-ness arises desperately. The sense of who is unfixatedness and this innate sense of no-thingness can be found and even experienced as ongoing timeless awareness in time. Innermost awareness in its manifestation can be experienced as whoness, no-thingness and open knowingness. The sense of me-ness is self-fixated, self-referencing and this me -ness can obscure the experiential arising of whoness.

The sense of me-ness reflects the being in mind alone, and the sense of whoness reflects being deeply within the awareness field.

Whoness manifests most directly as pause and within the pause. The pause is unbound in betweeness...the space in between.. transitional spaciousness. When the spaciousness of the breathless breath opens whoness can be felt as uncontained and unbound. Whoness is experiential openness....openess without a name or prior to name. We may say openness prior to mind. Dasein to use Heideggarian language.

When the breathless breath manifests the experience is always mysterious. What does breathless breath mean? Breathless means no breath, there is no breath. The word breath here, in this context signifies that there is no breath but there is respiration. There is this inner most experience of no breath, no inhaling or exhaling of air and yet there is respiration. There is a respiration without breath and beyond breath. For instance, in the Kechari mudra this breathless breath experience takes place. The breath stops and yet there is an inner sense of breathless respiration. 
This experience of respiration without breath is described in various traditions of eastern philosophy. In the Dzogchen tradition Longchenpa describes the experience in his great text Words and Meaning. This process is described in Chan Buddhism, and the Dao's Yan Xin Qi Gong. In Hinduism this breathless breath is described in Kashmir Shavism as well in various tantric Kundalini texts. Such descriptions are also in Huayen Buddhism.

Breathless respiration is qi, the primordial qi, primordial Shakti, primordial sublime vibrations of energy, primordial pulsations, the spanda. Breathless respiration is movement of the life force, the unfolding of vitalness, movements of the innermost field of awareness. Eros...life force.

Yet within this phenomenological experience of the appearing, shining forth radiating force of respiration is the sense of whoness beyond name, whoness as vibrating spaceousness. Breathless respiration is profound whoness, awareness as whoness with mind and yet beyond mind.

Respiration is qi and qi is both source and result simultaneously. Whoness is the breathless vibration of the energy and openness in union as knowingness. Respiration is the vibrational pulsation of field of spaciousness. Respiration is the unfolding vitalness of the field of primordial awareness.

Of course a person can also feel and experience Respiration and breath at the same time. Most often respiration and breath are simultaneous and in intimate relatedness. Most often breath and respiration are experientially intertwined. But in essence they are not completely identical. There is this intertwining of breath and respiration, intertwining of breath and qi, intertwining of breath and Shakti, breath and primordial energy. 
As the Qi gong masters describe to enter into the qi gong state is to enter the state of respiration. To enter the state of nonconceptual awareness of awareness is to enter the state of respiration, the state of subtle vibration. In a certain way we do not respirate but enter into the dimension of respiration. Respiration respirates us and inspires us.

In the truest sense breath is a function of respiration rather then respiration being a function of breath. This primordial respiration leads to an infinite diversity of experience. This respiration is continuous motion, ceaseless motion within stillness and stillness within the motion. This primordial respiration manifests the visible respiration of the breath. Respiration manifests the visible respiration of animating emptiness and the freeing of containing elements. Respiration is freeing of the fixatedness of thingness. Respiration frees us into spaciousness, free us into the space, light energetic continuum of experience. Respiration brings, creates, potentiality within facticity. Respiration brings forth and reflects the experience of timeless awareness in time.

Ultimately this energy of respiration is light. Illumination is forming forms of light as energy and light becoming energy becoming respiration. The pulsation of the light becomes the pulsation of the energy. The radiance of the light becomes the radiance of respiration. You can feel the experience of respiration as light pulsating. Light pulsating as you.

The light congeals and uncongeals becoming everything and anything. The light is always opening and closing. This opening and closing, this pulsating is the abasa that the Kashmir Shaivite masters describe. Nature forming luminous spheres of light becoming spheres of energy. The light is aliveness becoming the energy of aliveness becoming the respiration of aliveness. Psyche is light and light becomes radiance of respiration manifesting within flesh. Mind itself rises out of psyche, out of respiration. 
By being in the field of awareness, by being in the qi gong state, by living within the field of being all of the time or most of the time we live in this dimension of respiration and inspiration. Our respiration becomes attuned to the respiration within everyone. Respiration is attuned to respiration. This phenomenon is not simply physical breathing attuned to physical breathing. Rather this subtlemost attunement is respiration attuned to respiration of persons, of animals, of nature. We become attuned to the respiration dimension of experience. This is the opening of the sambogakaya dimension of experience within nirmanakaya. This is living within the sambogakya dimension. This is the realm of tantra.

\section{Tantra}

Tantra has a long history in many cultures. From the view and within the view that is being presented here, tantra is intimately connected to this subtle phenomenon of respiration. Tantra's roots are shamanistic. Tantra's roots both in India and in Tibet is shamanistic. Shamanism is the power of the invocation of primordial archetypal energies with the consequent manifestation of these energetic luminous realms in the world. In the language of Dzogchen tantra is the invocation of the sambogakaya realm into the realm of nirmanakaya. Tantric practices reconfigurate nirmanakaya experience in the light of bringing forth of sambogakaya dimensions of primordial dharmakaya of potential luminous space. The dieites and devas or dakinis were the manifestation of the primordial manifestion. The dieties and dakini are the archetypal's luminous energetic manifestaton of potential space of dharmakaya. They are the expanse of the dharmakaya, they are power and energy and the light. 
In the 3rd and 4th centuries tantric forms began to manifest in India both in Hinduism and Buddhism. The arising of tantra brought forth the experience and understanding that BLISS over comes suffering. Tantra arose as awareness became the path of embodiment rather than solely the path of dissociation. This embodiment was not only a function of the physical body of flesh but the subtle embodiment of light and energy and primordial awareness itself. Tantra was the manifestation of the experience of immanence of awareness and not simply the transcendental awareness as otherness.

The Tibetan, Je Tsongkhapa, who created the Gelugpa lineage would say that tantra was a practice of identification with the deities. This declaration took place in the 14th century. Tantra had already existed for over 1000 years. As expressed in the Bon tradition and Nyingma traditions of Tibet that were alive and shamanistic in origin tantra was the practice of the subtle light becoming energy and the attunement to this unfolding process. Tantra was attunement to the respiration dimension of human experience.

Tantra was the invocation of the sambogkaya realm of archetypal light and energies and having these archetypal configurations reorganize the nirmanakaya experience. The deities and dakinis or devas are the primordial manifestations of archetypal energies and light that could be brought forth in one's self and in one's circumstances. This realm of sambogkaya was the realm of primordial pulsations, sublime vibrations and the direct experience of this dimension of archetypal respiration. The archetypal sambogakaya was the manifestation of the dharmakaya, and the samabogakaya manifested into nirmanakaya. 


\section{Whoness As Purusha}

Where is the Whoness within this multidimensional unfolding of light and energy. This realm of manifestation of whoness was in all three dimensions or kayas. The realms of primordial whoness are expressed in the Indian traditions as purusha.

Purusha is person as whoness. The universe which is the manifestation of awareness and the manifestation of awareness in its diverse dimensions is always whoness. The purusha is a signifier for the cosmic person or cosmic knowingness as whoness who manifests into infinite forms of whoness, infinite forms of awareness. Purusha is primordial awareness as dharmakaya manifesting purusha as archetypal sambokakya which in turn is manifesting singular purusha as nirmanakaya.

In the manifestation of this world as the light becomes flesh there is the unfolding of immanence into the different dimensions or tatvas. There is a place or space or loca where awareness is becoming individuated as singular whoness within sambogakaya and then as nirmanakaya. Whoness manifests in the sambogkaya and nirmanakaya or whoness manifests within the elements within the body and mind yet as whoness nonetheless, whoness as respiration. This experience arises in meditation and the drama of becoming aware of awareness.

This dimension of whoness is the realm of tantra. Purusha is the subjective aspect of knowningness, the subjective side of primordial awareness. As the dharmakaya purusha is primordial nothingness manifesting itself as everything and anything. Cosmic person manifesting infinite forms of personhood. Personhood as the archetypal dimension. Personhood of the dakini, forms as the archetypal deities, personhood as fields. And then the archetypal dimension manifesting itself as worlds 
and individuals, singular purusha. People forms, animal forms. Personhood as mountains, seas, and lakes. And personhood as planets, suns and moons.

When the sense of person hood is lost, personal thingness dominates. The sense of knower and knowingness is lost. In this loss of subjectivity, the world is dead. The gods are dead. The earth is dead. Humanness itself is dead.

When the experiential and innermost sense of loss of purusha unfolds animals become commodities alone. When the innermost sense purusha is lost awareness itself becomes a thing.

At this point we will pause with the four noble truths which are simple forms of spiritual materialism. With the loss of the innermost experience of purusha the sacredness of human life disappears. The source of compassion dissolves. Subjectivity as consciousness is always multidimensional. Subjectivity is always cosmic, always archetypal and always human.

The essence of humaness is the purusha. Humaness is personhood personified. Humaness is the embodiment of the light. The essence of Purusha is light. Purusha is the light of the sun. Purusha is ground awareness as pure light. Purusha is the light as archetypal configurations. Purusha is the dark line of Troma Nagmo, the pure light of White Tara, the light of divine mother. Purusha is the light of human faces and the light of bodies, and the light of animals and trees and houses.

In the drama of becoming aware of awareness human beings shift from being located in mind alone and become located in the space of awareness who is purusha. Then the embodiment of the sphere of awareness brings forth the embodiment of purusha as one's own self. And from 
experiencing the light of purusha within one's self one experiences the light of purusha in others. By the power of invocation the power of the archetypal purusha is embodied and the dimensions of the purusha become more manifest. The power of attunement of purusha to its dimensions resonating to the dimensions of the purusha.

Besides the personification of the purusha, the pursha appears within the human heart...the hrdayam. The blue being within the heart is about 3 inches. The essence of the blue person is light, luminous brightness able to create everything and anything. The pure light is love. The purusha may also appear at times as the blue being who is the size of a human being. And the purusha may also appear as the cosmic blue being vast and infinite.

This same blue light appears in meditative experience, the radiance of meditative awareness. The purusha also appears as the blue person...neelakanta. This is person of human size and sometimes larger...the blue person is the embodiment of purusha as guru...and to experience this apparition is really great. The guru is the self-revelation of luminous awareness within its own forms and creations as manifestation.

To experience the purusha is to experience the mid-level or the archetypal dimension of human experience and to live within the archetypal dimension. And the capacity to dwell within the archetypal dimension will increase the transmission of the light from dharmakaya through sambogakaya into the flesh of nirmanakaya. 


\section{Conclusion}

The dimension of who-ness is the realm of tantra. Who-ness is the subjective aspect of knowingness, the subjective side of primordial awareness. When the sense of person hood is lost, non -personal thingness dominates. The sense of knower and knowingness is lost. In this lost of subjectivity, the world is dead. The gods are dead. Humanness is dead. 


\section{References}

Khan, Masud (1989) "Hidden Selves: Between Theory and Practice in Psychoanalysis" London: Karnac Books. ISBN: 9781849400749

Longchenpa (2011) "You Are The Eyes Of The World" Translated by Kennard Lipman and Merril Peterson. Snow Lion Publications, Ithaca, N.Y. USA ISBN: 978-1559393676

Scheibner Adiana (2014) "Beyond Good and Evil... is Paradise". Xlibris. ISBN: 9781499015614 